\title{
MODEL PRODUKTIVITAS BAGI HASIL AGROINDUSTRI GULA TEBU DALAM KEMITRAAN ANTARA PETANI DAN PERUSAHAAN: STUDI KASUS DI PG KREMBOONG, SIDOARJO
}

\section{GAINSHARING PRODUCTIVITY MODEL OF SUGARCANE AGROINDUSTRY IN PARTNERSHIP BETWEEN INDUSTRY AND FARMER: CASE STUDY AT PG KREMBOONG, SIDOARJO}

\author{
Wahyu Kanti Dwi Cahyani ${ }^{1 *}$, Marimin ${ }^{2}$, dan Sukardi ${ }^{2}$ \\ ${ }^{1)}$ Program Studi Teknologi Industri Pertanian, Fakultas Teknologi Pertanian, Institut Pertanian Bogor \\ Kampus IPB Darmaga, Bogor 16680 \\ E-mail:wahyukanti91@gmail.com \\ ${ }^{2}$ Departemen Teknologi Industri Pertanian, Fakultas Teknologi Pertanian, Institut Pertanian Bogor \\ Makalah: Diterima 12 April 2017; Diperbaiki 18 Juli 2017; Disetujui 26 Juli 2017
}

\begin{abstract}
In the agricultural activity especially sugarcane industries, there was untrust issue between farmers and sugarcane industry on yield measurement that impacting onfarmers' performance and income. The objective of this study was to formulate gainsharing productivity, with the following steps: 1) analyzed factors influencing the crops yield, 2) created a model for yield prediction, 3) constructed a model of gainsharing productivity, 4) analyzed the institutional to increase gainsharing productivity and 5) established recommendation strategy for gainsharing productivity. System thinking, multiple linear regression (SPSS) and production function research, ISM and SWOT-AHP were used as an approach and technique. Face validation from expert judgment was used for verification and validation. The result showed that sugarcane quality, brix, and pol analyzing gave a huge impact on crops yield. Yield prediction model generated $7.17 \%$ and $r^{2} 100 \%$. The second scenario of model (66:34 yield $<6 \% ; 70: 30$ yield 6.01\%-7.00\%, 72.5:27.5 yield 7.01\%-8.00\% and 75:25yield >8.01\%) and cash \& carry scheme were selected for the gainsharing model among farmers and sugarcane industry. Institutional partnership model generated one sub of the objective key element, two subs of the constraint key element, four subs of the requirement key element and one sub of the actor key element. The selected strategy for gainsharing productivity was the integration of sugarcane plantation with sugarcane industry with value 0.170 and cash \& carry with value 0.116 .
\end{abstract}

Keywords: gainsharing productivity (scanlon plan), institutional partnership, sugarcane agroindustry

\section{ABSTRAK}

Petani tidak mempercayai rendemen gula hasil pengukuran dari sistem pengukuran yang berlaku sehingga mempengaruhi kinerja dan pendapatan petani. Pada kajian ini, kami mendesain model produktivitas bagi hasil sebagai solusi dalam permasalahan tersebut meliputi analisis faktor-faktor yang mempengaruhi rendemen tebu, merancang model prediksi rendemen, membangun model produktivitas bagi hasil, menganalisis kelembagaan untuk meningkatkan produktivitas bagi hasil dan menyusun strategi untuk meningkatkan produktivitas gula. Metode yang digunakan berdasarkan pada pendekatan sistem, memakai regresi linier berganda dan pendekatan fungsi produksi, ISM dan SWOT-AHP, serta verifikasi dan validasi menggunakan justifikasi pakar. Hasil penelitian adalah kualitas tebu, brix dan pol menjadi faktor yang mempengaruhi rendemen. Model prediksi rendemen memperoleh nilai 7,17\% dan $\mathrm{r}^{2} 100 \%$. Model produktivitas bagi hasil yang terpilih adalah model skenario $66: 34$ rendemen $<6 \%$; 70:30 rendemen $6,01 \%-7,00 \%$, 72,5:27,5 rendemen $7,01 \%-8,00 \%$ dan $75: 25$ rendemen $>8,01 \%$ dan sistem beli secara putus. Analisis kelembagaan dalam kemitraan memperolehsatu sub elemen kunci tujuan, dua sub elemen kunci kendala, empat sub elemen kunci kebutuhan, dan satu sub elemen kunci pelaku. Berdasarkan hasil diatas, maka usulan strategi yang terpilih untuk produktivitas bagi hasil adalah pengelolaan lahan tebu yang terintegrasi dengan pengelolaan pabrik dan sistem beli.

Kata kunci : produktivitas bagi hasil (scanlon plan), kelembagaan kemitraan, agroindustri gula

\section{PENDAHULUAN}

Pabrik Gula (PG) Kremboong memiliki kapasitas giling 2.700 ton cane per day (TCD) yang merupakan salah satu dari empat PG yang masih dapat bertahan di didaerah Sidoarjo dan sekitarnya. Pengurangan PG aktif disebabkan karena luas lahan yang semakin menyempit, penurunan motivasi petani menanam tebu, disparitas harga gula terhadap komoditas lain, dan kapasitas giling (Indrawanto $e t$ al., 2010; Fahrizal et al., 2014). Rendemen tebu selain menjadi tolok ukur dalam bagi hasil juga menjadi gambaran untuk mengetahui peningkatan produktivitas tebu. Skema yang berlakuantara petani dan PG sesuai dengan Surat Keputusan (SK) Kementan dan sistem pengukuran rendemen 
menggunakan sistem krepyak mini. Namun, skema ini dinilai merugikan petani menyebabkan ketidakpercayaan. Selain itu, dalam proses pengolahan tebu di pabrik, tebu petani yang masuk pabrik digabungkan menjadi satu dan menggunakan rendemen efektif yang merupakan rerata. Hal ini yang memicu ketidakpercayaan petani dan menuntut transparansi pengukuran rendemen berbasis individu (Purwono, 2002). Rendemen mempengaruhi motivasi, kontinuitas pasokan bahan baku serta jalinan kerjasama antara PG dan petani, kapasitas giling, efisiensi pabrik gula, teknik budidaya tebu yang tepat, produktivitas bagi hasil antara petani dan perusahaan, pendapatan dan penjulan gula (Mardianto et al., 2005; Susila et al., 2005; Rahmatulloh et al., 2007). Ketepatan dalam mekanisme pengukuran rendemen yang diimbangi dengan kualitas tebu petani yang baik menjadi faktor yang sangat mempengaruhi kepercayaan petani. Oleh karena itu, penting adanya analisis faktorfaktor yang mempengaruhi rendemen dan memprediksi nilai rendemen.

Produktivitas bagi hasil adalah distribusi kekayaan atau kemakmuran yang diperoleh dari jalinan hasil kerjasama yang akan diberikan kepada pekerja sebagai hasil dari peningkatan produktivitas yang dituangkan dalam formula sesuai dengan kesepakatan (Ross dan Ross, 1984). Pemberian bagi hasil berdasarkan produktivitas memungkinkan saving cost dan peningkatan produktivitas (Kim, 2005). Produktivitas bagi hasil agroindustri tebu antara petani dan PG berdasarkan nilai rendemen. Produktivitas bagi hasil antara petani dan perusahaan sesuai dengan SK Kementan Bimas 1962 dan kontrak kerjasama dalam jalinan kemitraan. Oleh karena itu, perubahan formula bagi hasil dapat menjadi solusi untuk meningkatkan motivasi petani (Nahdodin, 2012).

Bentuk kemitraan antara petani dan PG adalah pola kerjasama sub kontrak yang memungkinkan petani dan pabrik gula memiliki peran yang sama serta saling menguntungkan serta ada keterkaitan lembaga pendukung didalamnya. Lembaga yang terlibat meliputi kelompok tani, industri, koperasi, asosiasi petani dan dinas perkebunan. Munculnya permasalahan moral hazard, adverse selection, asymetric information yang telah menjadi budaya oleh masing-masing lembaga baik dari petani dan industri mengganggu kelancaran, keharmonisan dan keadilan dalam penerapan bagi hasil yang transparan dan saling menguntungkan dalam kemitraan (Suhada et al., 2012). Hal ini akan berdampak pada tidak berjalannya kontrak kerjasama dalam kemitraan. Oleh karena itu, analisis kebutuhan kelembagaan untuk menyusun model kelembagaan dalam mencapai produktivitas bagi hasil yang lebih baik dengan tujuan untuk mempermudah dalam pengontrolan dan pengawasan dalam kelembagaan dapat dilakukan. Tujuan penelitian ini adalah: 1) menganalisis faktor-faktor yang mempengaruhi rendemen dalam produktivitas bagi hasil dengan pendekatan sistem; 2) menyusun model prediksi rendemen individu petani secara individu menggunakan regeresi linier berganda; 3) menyusun model produktivitas bagi hasil agroindustri gula dengan pendekatan fungsi produksi; 4) menyusun model kelembagaan menggunakan Interpretive Structure Modelling (ISM); dan 5) menyusun rekomendasi strategi untuk meningkatkan produktivitas bagi hasil menggunakan StrengthWeakness-Opportunity-Threat (SWOT) dan Analytical Hierarchy Process (AHP).

\section{METODE PENELITIAN}

Penelitian ini dilaksanakan pada bulan JuliDesember 2016. Tempat penelitian di PG Kremboong, Sidoarjo. Tahapan penelitian mengacu pada metodologi pemecahan masalah menggunakan pendekatan sistem (Eriyatno, 1999; Marimin, 2008). Verifikasi dan validasi menggunakan program komputer dan face validation (Sargent, 2011). Tahapan penelitian dapat dilihat pada Gambar 1.

\section{Analisis Faktor-Faktor yang Mempengaruhi Rendemen}

Analisis faktor-faktor yang mempengaruhi rendemen berdasarkan pendekatan sistem dan pembentukan regresi linier berganda. Data dikumpulkan melalui wawancara dan diskusi dengan pakar untuk pemilihan faktor atau variabel. Selanjutnya, menganalisis hubungan antar variabel terikat dan variabel bebas dalam persamaan regresi linier berganda (persamaan 1).

$\mathrm{Y}_{\mathrm{i}}=\mathrm{a}_{0}+\mathrm{a}_{1} \mathrm{X}_{1 \mathrm{i}}+\mathrm{a}_{2} \mathrm{X}_{2 \mathrm{i}}+\mathrm{a}_{3} \mathrm{X}_{3 \mathrm{i}}+\ldots+\mathrm{a}_{\mathrm{n}} \mathrm{X}_{\mathrm{ni}}+\varepsilon_{\mathrm{i}}$

Keterangan:

\begin{tabular}{|c|c|c|}
\hline i & : & $1,2, \ldots \mathrm{k}$ \\
\hline $\mathrm{Y}_{\mathrm{i}}$ & & $\begin{array}{l}\text { variabel terikat } \\
\text { rendemen }(\%))\end{array}$ \\
\hline $\mathrm{X}_{1 \mathrm{i}}, \mathrm{X}_{2 \mathrm{i}}, \ldots, \mathrm{X}_{\mathrm{ni}}$ & : & $\begin{array}{l}\text { variabel bebas (nilai pol, brix, } \\
\text { waktu tunggu (menit), jumlah } \\
\text { tebu (ku), kualitas tebu (B } \\
\text { dan } \mathrm{C} \text { ), nilai nira (NN), dan } \\
\text { nilai pH) }\end{array}$ \\
\hline$a_{0}, a_{1}, a_{2}, a_{3} \ldots a_{n}$ & : & $\begin{array}{l}\text { parameter regresi yang belum } \\
\text { diketahui nilainya }\end{array}$ \\
\hline & & nilai kesalahan \\
\hline
\end{tabular}

\section{Model Prediksi Rendemen}

Penyusunan model prediksi rendemen terdiri dari: 1) membentuk persamaan regresi linier berganda; 2) identifikasi model; 3) membangun model; 4) pemilihan model terbaik; 5) membentuk model prediksi dalam bentuk persamaan regresi linier berganda yang baru; dan 6) menganalisis mekanisme pengukuran rendemen dan kondisi kinerja PG. 


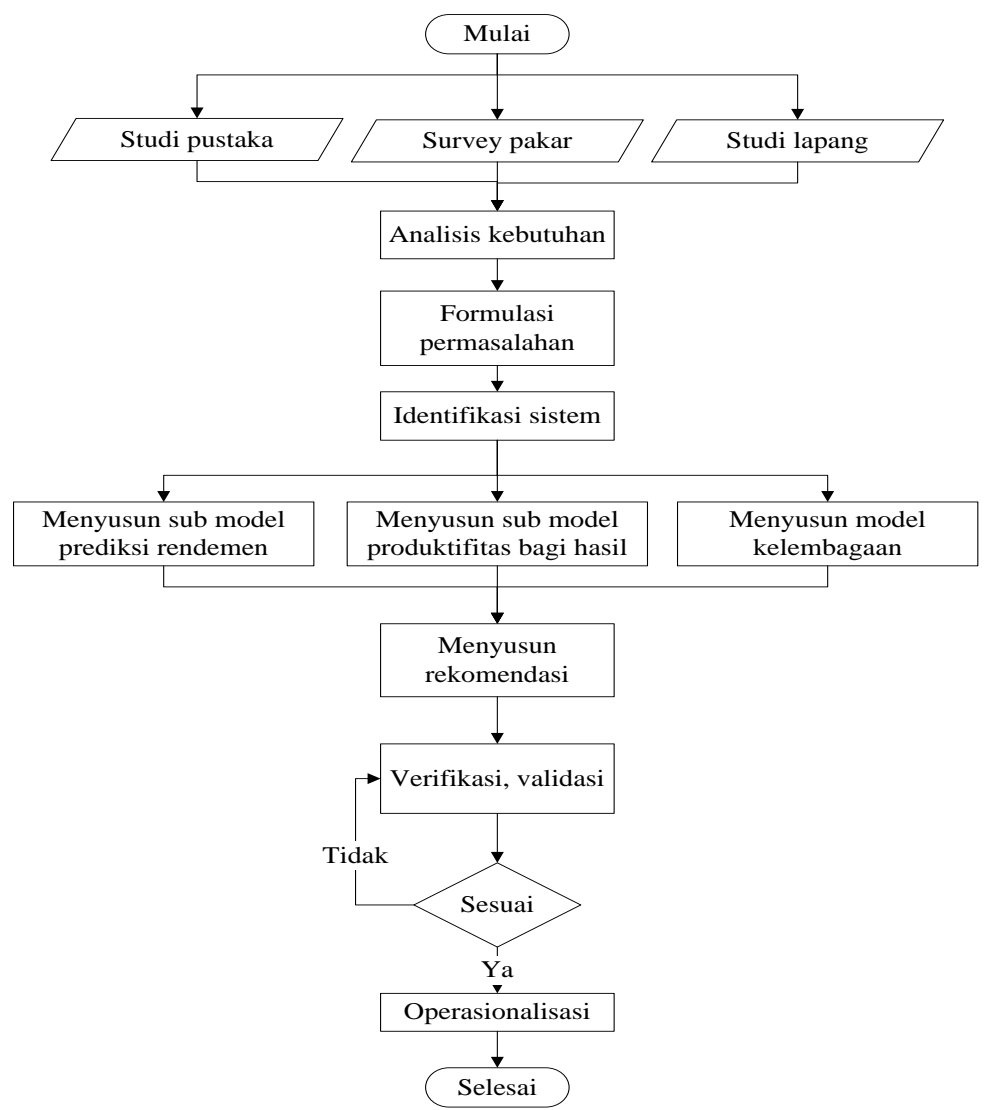

Gambar 1.Tahapan penelitian

Data dikumpulkan dengan cara mengukur dan menghitung nilai waktu tunggu, rendemen, kualitas, jumlah tebu, nilai nira tebu, hasil gula per truk. Analisis data menggunakan bantuan software SPSS dengan metode backward merujuk pada Samosir et al., 2014).

\section{Model Produktivitas Bagi Hasil}

Penyusunan model produktivitas bagi hasil terdiri dari: 1) menganalisis SK Mentan Bimas tentang bagi hasil; 2) melakukan diskusi dengan akademisi dan pakar; 3) menganalisis penerimaan dan pengeluaran berdasarkan fungsi produksi dan scanlon plan; 4) menyusun model skema produktivitas bagi hasil dengan mengagregasikan fungsi produksi dengan kesepakatan dalam bagi hasil yang terjalin antara petani dan perusahaan gula yang dapat dilihat pada persamaan 2 dan 3 (Debertin, 1986; Paykeni et al., 2010); 5) menganalisis model produktivitas bagi hasil; 6) menganalisis sejarah nilai rendemen tebu petani 5 tahun terakhir; 7) memilih model terbaik; dan 8) model produktivitas bagi hasil terbentuk.

$$
\begin{aligned}
& \mathrm{Pd}=[\mathrm{p} \times \mathrm{Q}]-\left\{\left(\frac{\overline{\mathrm{CT}}}{\mathrm{Q}}+\frac{\overline{\mathrm{CV}}}{\mathrm{Q}}\right) \mathrm{x}\left[\mathrm{Q}=\mathrm{f}\left(\mathrm{X}_{1}, \mathrm{X}_{2}, \mathrm{X}_{3}, \ldots, \mathrm{X}_{\mathrm{n}}\right)\right]\right\} \\
& \pi=\mathrm{r}\left(\overline{\mathrm{C}} \mathrm{f}\left(\mathrm{X}_{1}, \mathrm{X}_{2}, \mathrm{X}_{3}, \ldots, \mathrm{X}_{\mathrm{n}}\right)\right) \ldots \ldots \ldots \ldots \ldots \ldots \ldots \ldots \ldots \ldots \ldots \ldots \ldots
\end{aligned}
$$

Keterangan :

$$
\begin{array}{lll}
\mathrm{f}\left(\mathrm{X}_{1}, \mathrm{X}_{2}, \mathrm{X}_{3}, \ldots, \mathrm{X}_{\mathrm{n}}\right): & \text { fungsi input produksi } \\
& \text { yang digunakan } \\
\overline{\mathrm{C}}\left(\frac{\mathrm{CT}}{\mathrm{Q}} ; \frac{\overline{\mathrm{CV}}}{\mathrm{Q}}\right) & : \begin{array}{l}
\text { rata-rata biaya produksi } \\
\text { (rata-rata biaya tetap dan } \\
\text { biaya variabel) }
\end{array} \\
\mathrm{P} & : \text { Rp/unit } & \text { harga (Rp) } \\
\mathrm{Pd} & : & \text { pendapatan penjualan } \\
& \text { (Rp) } \\
\pi & : \text { keuntungan (profit) } \\
r & : \text { rasio bagi hasil }
\end{array}
$$

\section{Penyusunan Model Kelembagaan}

Penyusunan model kelembagaan kemitraan antara petani dan pabrik gula dilakukan untuk menemukan elemen-elemen kunci dari relasi fungsional yang selama ini terbangun menggunakan metode ISM. Penyusunan model kelembagaan berdasarkan diskusi dengan pakar, kondisi di pabrik gula dan wawancara dengan pihak petani.Penentuan elemen-elemen kunci kelembagaan yaitu : 1) elemen kunci tujuan; 2) elemen kunci kendala; 3) kunci kebutuhan; dan 4) elemen kunci pelaku.

\section{Penyusunan Rekomendasi}

SWOT-AHP digunakan dalam menyusun rekomendasi strategis untuk perusahaan berdasarkan informasi dari wawancara dengan pakar, pihak perusahaan dan analisis legal berdasarkan peraturan pemerintah. Tahapan analisis SWOT-AHP adalah: 1) Analisis legal meliputi analisis isu, deskripsi hukum-hukum peraturan yang berkaitan dengan 
produktivitas bagi hasil petani dan perusahaan gula; 2) analisis situasional berdasarkan kondisi di lingkup perusahaan dan petani; 3) penyusunan struktur hirarki yang terdiri dari tiga tingkatan yaitu objective, factors dan rekomendasi strategi (Gorener et al., 2012); 4) perbandingan berpasangan; dan 5) agregasi menggunakan matriks SWOT untuk penyusunan rekomendasi strategis (Osuna et al.,2007).

\section{HASIL DAN PEMBAHASAN}

\section{Analisis Faktor-Faktor yang Mempengaruhi Rendemen}

Faktor-faktor yang mempengaruhi rendemen tebu dapat diperoleh dari hasil analisis menggunakan software statistik. Rendemen sebagai variabel terikat (Y) dan faktor-faktor yang mempengaruhi rendemen sebagai variabel bebas $\left(\mathrm{X}_{1}, \mathrm{X}_{2} \ldots \mathrm{X}_{\mathrm{n}}\right)$. Variabel bebas yang digunakan untuk penelitian ini terdiri dari waktu tunggu (menit), jumlah tebu $(\mathrm{ku})$, nilai brix, nilai pol, nilai $\mathrm{pH}$, nilai nira (NN), dan kualitas tebu (B dan C).Hasil yang diperoleh menunjukkan bahwa nilai $\mathrm{F}$ hitung sebesar 5.616.645,981 dibandingkan nilai $\mathrm{F}$ tabel 2,662 dan nilai signifikansi kurang dari 0,05 , berarti minimal ada satu variabel bebas yang berpengaruh terhadap variabel terikat.

Berdasarkan uji $\mathrm{T}$ diperoleh 3 dari 7 variabel bebas yang berpengaruh secara signifikan pada faktor-faktor yang mempengaruhi rendemen di PG Kremboong. Nilai signifikansi masing-masing variabel bebas kurang dari 0,05 maka setiap variabel bebas tersebut berpengaruh nyata terhadap variabel terikat rendemen. Variabel bebas yang menjadi faktor yang mempengaruhi rendemen secara signifikan meliputi: 1) kriteria MBS (Masak Bersih Segar) untuk kualitas yang menjadi syarat diterima tidaknya tebu untuk digiling. Kriteria MBS di PG Kremboong terdiri dari kualitas B dan C; 2) brik merupakan nilai jumlah zat padat semu yang larut (dalam g) setiap 100 g. Nilai brik menunjukkan kematangan tebu dan siap untuk digiling. Batas minimum nilai brix PG Kremboong adalah 15,0; dan 3) pol adalah jumlah gula (dalam gram) yang ada dalam setiap $100 \mathrm{~g}$ larutan yang diperoleh dari pengukuran polarimeter secara langsung.

\section{Model Prediksi Rendemen}

Membangun model prediksi rendemen tebu petani dengan pendekatan analisis regresi linier bergandadiperoleh:

$$
\mathrm{Y}_{\mathrm{i}}=0,596+0,005 \mathrm{X}_{1}-0,313 \mathrm{X}_{2}+0,258 \mathrm{X}_{3}+\varepsilon
$$

\section{Keterangan:}

$\mathrm{Y}_{1}$ : nilai prediksi rendemen tebu petani (\%)

$\mathrm{X}_{1}$ : $\quad$ kualitas tebu (B dan C)

$\mathrm{X}_{2}$ : nilai brik hasil analisa pabrik gula

$\mathrm{X}_{3}$ : nilai pol baca hasil analisa pabrik gula
Simulasi prediksi nilai rendemen diperoleh sebesar 7,17\%. Nilai error untuk $\left(X_{1}=0,001, X_{2}=0,000\right.$, dan $\left.X_{3}=0,000\right)$. Berdasarkan uji $\mathrm{R}$ untuk mengetahui kelayakan model yang dibangun maka diperoleh nilai koefisien determinasi $r^{2}=1,000(100 \%)$. Ini menunjukkan bahwa semua variasi variabel rendemen sebagai variabel dependent (Y) dapat dijelaskan oleh 3 variabel independent $\left(\mathrm{X}_{1}, \mathrm{X}_{2}\right.$ dan $\left.\mathrm{X}_{3}\right)$.

\section{Model Produktivitas Bagi Hasil}

Penyusunan produktivitas bagi hasil terdiri dari dua usulan meliputi skema bagi hasil yaitu dengan perbedaan persentase kesepakatan dalam bagi hasil antara petani dan perusahaan serta usulan dengan sistem beli putus.Model formula dalam produktivitas bagi hasil dan sistem beli putus berdasarkan persamaan 2 dan 3 serta perolehan hasil penjualan gula dengan harga jual dan jumlah biaya untuk penggunaan sumber daya untuk memproduksi gula.

\section{Skenario Pertama}

Produktivitas bagi hasil merupakan distribusi kekayaan yang diperoleh perusahaan dari hasil jalinan kerjasama antara petani dan perusahaan yang akan diberikan kepada petani berdasarkan peningkatan produktivitasnya. Produktivitas gula dapat dilihat berdasarkan nilai rendemen gula yang dihasilkan oleh pabrik gula dan produktivitas sumberdaya seperti produktivitas tenaga kerja, produktivitas jam kerja mesin, produktivitas bahan baku, produktivitas lama hari, dan produktivitas produksi gula. Semakin tinggi nilai rendemen tebu yang dihasilkan maka semakin tinggi produktivitas pabrik untuk produksi gula.

Penyusunan produktivitas bagi hasil pada skenario pertama terdiri dari 3 skema yaitu skema yang sedang diterapkan di PG dan 2 skema usulan berdasarkan diskusi dengan pakar dan menganalisis SK Mentan Bimas. Usulan model skema bagi hasil antara petani dan PG (Tabel 1). Tujuan perbaikan usulan skema bagi hasil meningkatkan produktivitas bagi hasil antara petani dan perusahaan. Hasil usulan pada Tabel 1 kemudian dilakukan simulasi dimulai dari kondisi nilai rendemen $<6 \%$ sampai $>8 \%$. Hasil simulasi divisualisasikan dalam bentuk grafik yang dapat dilihat pada Gambar 2.

Perhitungan berdasarkanpersamaan 2 dan 3 diperoleh bahwa semakin tinggi rasio bagi hasil yang disepakati oleh pihak PG dan petani maka semakin tinggi pendapatan yang akan berpengaruh terhadap motivasi petani dalam menanam tebu. Ratarata hasil analisis penerimaan dan pendapatan petani berdasarkan persamaan (2 dan 3) pada kondisi nilai rendemen yang berbeda (Gambar 2). 
Tabel 1. Usulan model skema bagi hasil antara PG dan petani

\begin{tabular}{crrr}
\hline \multirow{2}{*}{ Skema } & \multicolumn{2}{c}{ Bagi hasil } & \multicolumn{1}{c}{ Rendemen } \\
\cline { 2 - 3 } & $\begin{array}{c}\text { Petani } \\
(\boldsymbol{\%})\end{array}$ & PG (\%) & \multicolumn{1}{c}{$(\boldsymbol{\%})$} \\
\hline \multirow{2}{*}{ PG } & 66 & 34 & $<6,0$ \\
& 70 & 30 & $6,01-8,0$ \\
& 75 & 25 & $>8,01$ \\
\hline \multirow{4}{*}{66} & 34 & $<6,0$ \\
& 68 & 32 & $6,01-6,50$ \\
1 & 70 & 30 & $6,51-7,0$ \\
& 72 & 28 & $7,01-$ \\
& & & 7,50 \\
& 74 & 26 & $7,51-8,0$ \\
& 76 & 24 & $>8,01$ \\
\hline \multirow{2}{*}{2} & 66 & 34 & $<6,0$ \\
& 70 & 30 & $6,01-7,0$ \\
& 72,5 & 27,5 & $7,01-8,0$ \\
& 75 & 25 & $>8,01$ \\
\hline
\end{tabular}

Sumber: Permentan dan usulan model (2017)

Rata-rata keuntungan yang diperoleh petani dan perusahaan dengan menerapkan skema PG: 1) rendemen $<6 \%$ petani akan mendapatkan keuntungan Rp 449.317/ha dan perusahaan mengalami kerugian mencapai Rp (3.925.358/ha); 2) rendemen $6,01 \%-8,0 \%$ dan keuntungan petani dapat mencapai $\mathrm{Rp}$ 11.735.300/ha dan keuntungan perusahaan mencapai $\mathrm{Rp}$ 1.383.252/ha; dan 3) rendemen $>8,01 \%$ petani mendapatkan keuntungan Rp 23.768.454/ha dan keuntungan perusahaan $\mathrm{Rp}$ 5.944.691/ha. Keuntungan yang diperoleh petani dan perusahaan dengan skema 1: 1) rendemen $<6 \%$ petani mendapatkan keuntungan $\mathrm{Rp}$ 449.317/ha dan perusahaan mengalami kerugian $\mathrm{Rp}(3.925 .358)$ /ha; 2) rendemen $6,01 \%-8,0 \%$ keuntungan petani $\mathrm{Rp}$ 11.728.342/ha dan keuntungan perusahaan $\mathrm{Rp}$ 1.390.210/ha; dan 3) rendemen $>8,01 \%$ keuntungan petani Rp 23.848.092/ha dan keuntungan perusahaan Rp 5.865.053/ha. Keuntungan yang diperoleh petani dan perusahaan dengan skema 2: 1) rendemen $<6,0 \%$ keuntungan petani mencapai Rp 449.317/ha dan perusahaan rugi $\mathrm{Rp}(3.925 .358) / \mathrm{ha} ; 2)$ rendemen
6,01\%-8,01\% petani akan mendapatkan keuntungan Rp 11.752.616/ha, keuntungan perusahaan mencapai

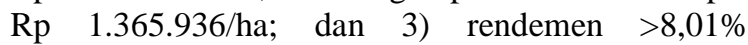
keuntungan petani mencapai Rp 23.834.930/ha dan perusahaan akan mendapatkan keuntungan Rp 5.878.215/ha.

Gambar 2 menunjukkan perolehan rata-rata keuntungan petani dan perusahaan dengan berbeda persentase bagi hasil yang meliputi skema PG, skema ke-1, dan skema ke-2 tidak berbeda secara signifikan. Namun, perbedaan persentase bagi hasil yang lebih menguntungkan petani adalah skema ke-2 karena perolehan pendapatan dan keuntungan petani yang lebih besar dibandingkan skema PG dan 1 .

Model produktivitas bagi hasil yang ada divalidasi berdasarkan judgment pakar dengan pertimbangan perolehan peningkatan pendapatan petani dan kondisi nilai rendemen petani. Pemilihan usulan skema ke-2 karena pada usulan skema ke-1 pada saat rendemen $6,01 \%-7,00 \%$ mengalami penurunan pendapatan dibandingkan dengan skema ke-2.

\section{Skenario Kedua}

Simulasi skenario kedua melalui sistem beli putus. Dimana, sistem beli putus adalah sistem pembelian tebu berdasarkan harga jual tebu. Keuntungannyaadalah risiko tingkat efisiensi pabrik dan ketidaklancaran dalam proses pengolahan serta pengukuran rendemen yang tidak akurat tidak akan menjadi risiko yang ditanggung oleh petani. Harga tebu untuk rendemen $<6 \%$ mencapai Rp $40.752 / \mathrm{kw}$, rendemen $6,01 \%-8,00 \%$ dengan harga tebu yang ditawarkan $\mathrm{Rp} 55.926 / \mathrm{kw}$, rendemen $>8,00 \%$ dengan harga tebu yang ditawarkan Rp 721.105/kw.

Semakin tinggi kualitas tebu yang dapat dilihat dari nilai rendemen tebunya maka semakin tinggi harga jual tebu setiap tonnya. Penetapan harga jual tebu kepada petani akan meningkatkan produktivitas dan motivasi petani dalam menanam tebu. Rata-rata perolehan keuntungan antara petani dan perusahaan dapat dilihat pada Gambar 3.

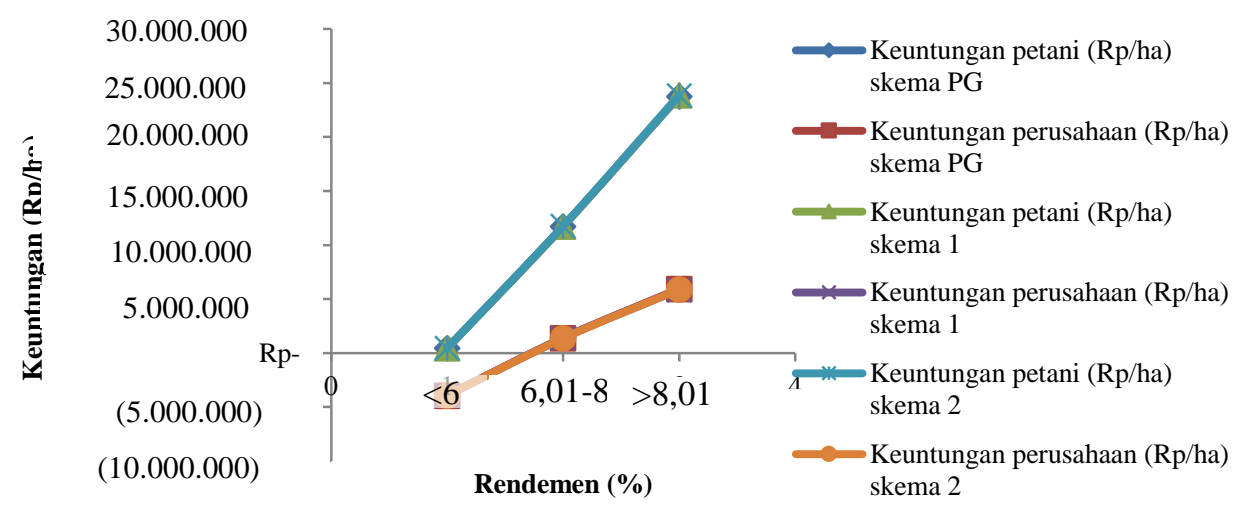

Gambar 2. Rata-rata keuntungan petani dan perusahaan ( $\mathrm{Rp} / \mathrm{ha})$ pada skenario pertama 


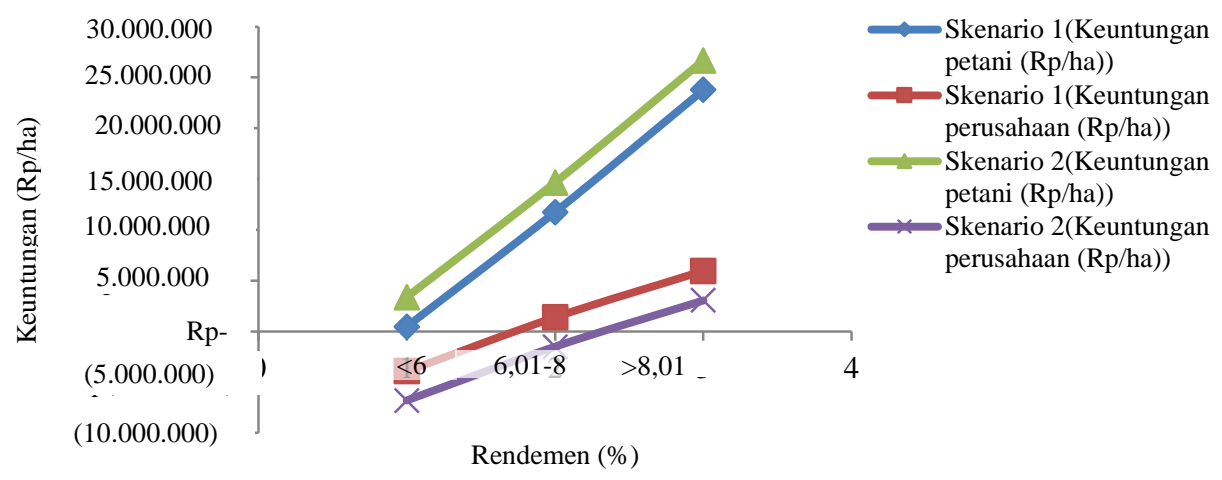

Gambar 3. Rata-rata keuntungan petani dan perusahaan pada skenario kedua

Petani dan perusahaan sudah memperoleh untungpada saat menerapkan sistem bagi hasil. Namun, bagi petani akan lebih menguntungkan apabila menerapkan sistem beli putus. Rata rata keuntungan petani dan perusahaan dengan sistem bagi hasil adalah: 1) rendemen $<6 \%$, petani akan mendapatkan keuntungan $\mathrm{Rp} 449.317 / \mathrm{ha}$ dan perusahaan mengalami kerugian $\mathrm{Rp}(3.925 .358) / \mathrm{ha}$; 2) rendemen $6,01-8,0 \%$ petani mendapatkan keuntungan Rp 11.735.300/ha dan perusahaan mendapatkan Rp 1.383.252/ha; dan 3) rendemen $>8,01 \%$, keuntungan petani Rp 23.768.454/ha dan perusahaan Rp 5.944.691/ha. Rata rata keuntungan petani dan perusahaan dengan sistem beli putus adalah : 1) rendemen $<6 \%$, petani mendapatkan keuntungan $\mathrm{Rp} 3.349 .949 / \mathrm{ha}$ dan perusahaan $\mathrm{Rp}$ $(6.825 .990) / \mathrm{ha} ; 2)$ rendemen $6,01-8,0 \%$ petani mendapatkan keuntungan $\mathrm{Rp}$ 14.635.932/ha dan perusahaan mengalami kerugian $\mathrm{Rp}(1.517 .380) / \mathrm{ha}$; dan 3) rendemen $>8,01 \%$, keuntungan petani $\mathrm{Rp}$ 26.669.086/ha dan perusahaan mendapatkan keuntungan Rp 3.044.059/ha.

Gambar 3 menunjukkan bahwa keuntungan petani lebih tinggi dengan menerapkan sistem beli putus dan keuntungan perusahaan lebih tinggi dengan menerapkan sistem bagi hasil. Hal ini disebabkan karena perusahaan menanggung pembiayaan tebu untuk membeli tebu sesuai dengan harga tebu setiap tonnya. Sebaliknya, dalam sistem bagi hasil, perusahaan hanya menanggung biaya proses pengolahannya. Keuntungan sistem beli putus:

1. Sistem pembayaran tebu dapat dilakukan di muka tanpa menunggu gula terjual.

2. Keuntungan dan produktivitas petani serta perusahaan lebih tinggi.

3. Kualitas tebu dan nilai rendemen petani lebih tinggi.

4. Prestasi petani dan perusahaan akan lebih bersifat individual dan transparan.

\section{Skenario Ketiga}

Nilai harga tebu untuk skenario ke-3 kondisi sama-sama menguntungkan dengan menerapkan sistem beli putus. Kemampuan harga beli tebu yang diberikan perusahan untuk kondisi saling menguntungkan yaitu rendemen $<6 \%$ harga tebu Rp 35.928/kw tebu, rendemen 6,01-8,0\% dengan harga tebu $\mathrm{Rp} 52.477 / \mathrm{kw}$ tebu dan rendemen $>8 \%$ harga tebu Rp 72.096/kw tebu. Hasil simulasi skenario ke-3 (Gambar 4).

Gambar 4 menunjukkan bahwa rata-rata keuntungan petani dan perusahaan lebih menguntungkan dengan menerapkan sistem bagi hasil. Namun, petani akan lebih menguntungkan apabila menerapkan sistem beli putus. Rata rata keuntungan petani dan perusahaan pada skenario ke1 adalah: 1) rendemen $<6 \%$, petani mendapatkan keuntungan Rp 449.317/ha dan perusahaan mengalami kerugian $\mathrm{Rp}(3.925 .358) / \mathrm{ha} ; 2)$ rendemen $6,01-8,0 \%$ petani mendapatkan keuntungan mencapai $\mathrm{Rp} 11.735 .300 / \mathrm{ha}$ dan perusahaan mendapatkan Rp 1.383.252/ha; dan 3) rendemen $>8,01 \%$, keuntungan petani $\mathrm{Rp} 23.768 .454 /$ ha dan keuntungan perusahaan $\mathrm{Rp} 5.944 .691 /$ ha. Rata rata keuntungan petani dan perusahaan pada skenario ke2 adalah : 1) rendemen $<6 \%$, petani mendapatkan keuntungan Rp 3.349.949/ha dan perusahaan Rp (6.825.990)/ha; 2) rendemen $6,01-8,0 \%$ petani mendapatkan keuntungan $\mathrm{Rp}$ 14.635.932/ha dan perusahaan mengalami kerugian Rp (1.517.380)/ha; dan 3) rendemen $>8,01 \%$, keuntungan petani $\mathrm{Rp}$ 26.669.086/ha dan keuntungan perusahaan mencapai Rp 3.044.059/ha.

Rata rata keuntungan petani dan perusahaan pada skenario ke-3 adalah: 1) rendemen $<6 \%$, petani mendapatkan keuntungan Rp 911.772/ha dan keuntungan perusahaan Rp 1.936.844/ha; 2) rendemen 6,01-8,0\% petani mendapatkan keuntungan $\mathrm{Rp} 12.071 .010 / \mathrm{ha}$ dan perusahaan mendapatkan Rp 1.047.542/ha; dan 3) rendemen $>8,01 \%$, keuntungan petani mencapai Rp 26.662.511/ha dan perusahaan $\mathrm{Rp} 3.050 .634 / \mathrm{ha}$. Hasil simulasi skenario ke-3 menunjukkan keuntungan petani dengan perusahaan dengan kondisi harga dasar tebu. keuntungan yang diperoleh petani lebih rendah dibandingkan dengan perolehan keuntungan pada skenario ke-2. Hal ini disebabkan karena rendahnya harga beli tebu. 


\section{Mekanisme Pengukuran Rendemen}

Mekanisme dan teknik pengukuran rendemen tebu di PG Kremboong sudah cukup baik menggunakan teknik sistem krepyak mini, yakniminiatur atau tiruan dari susunan krepyak gilingan asli di pabrik dan akan berputar sesuai dengan perputaran krepyak gilingan asli.PG Kremboong memiliki dua meja tebu dengan kapasitas giling 2.700 TCD. Penerapan pengukuran kualitas tebu tiap truk/lori telah cukup baik dan berhasil dilaksanakan secara akurat karena maksimal jumlah meja tebu dikatakan akurat berjumlah 1-2 meja tebu. Apabila PG memiliki kapasitas besar dengan jumlah meja tebu 3 buah perlu adanya pengaturan khusus dalam menata antrian truk/lori agar tidak tercampur truk/lori yang berbeda kepemilikan (LRPI, 2005; Saputro, 2013). Mekanisme pengukuran rendemen meliputi sistem pengukuran krepyak mini (Gambar 5) dan sistem core sampler (Gambar 6).

Hasil pengukuran teknik Core Sampler (CS) dapat direkomendasikan sebagai teknik penetapan rendemen individu dibandingkan dengan sistem krepyak mini. Teknik tersebut lebih akurat, terpercaya, obyektif, dan mudah dilakukan untuk penetapan rendemen tebu secara individu petani (Mulyadi, 2006; Saputro, 2013). Selain itu, penerapan pengukuran rendemen menggunakan -CS dapat mengurangi risiko pabrik dan efisiensi pabrik yang menjadi beban petani.

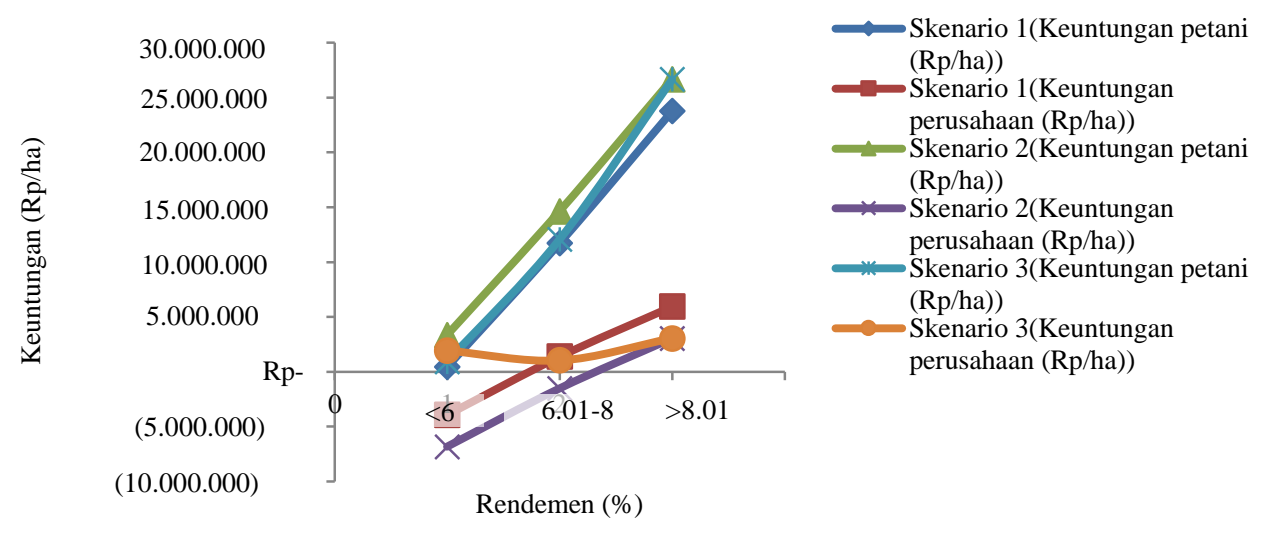

Gambar 4. Rata-rata keuntungan petani dan perusahaan pada skenario1,2, dan 3

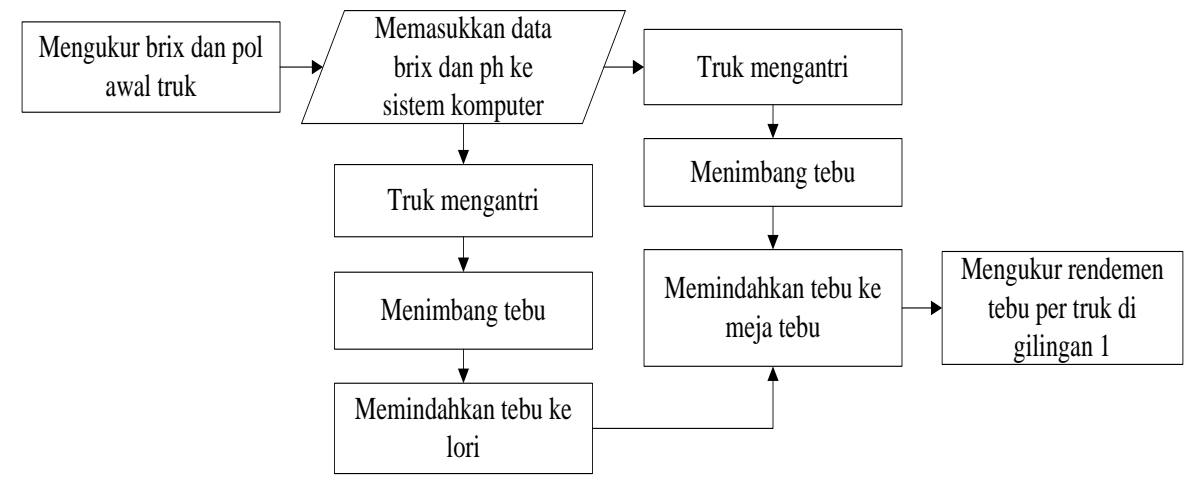

Gambar 5. Mekanisme alur pengukuran rendemen sistem krpeyak mini di PG Kremboong

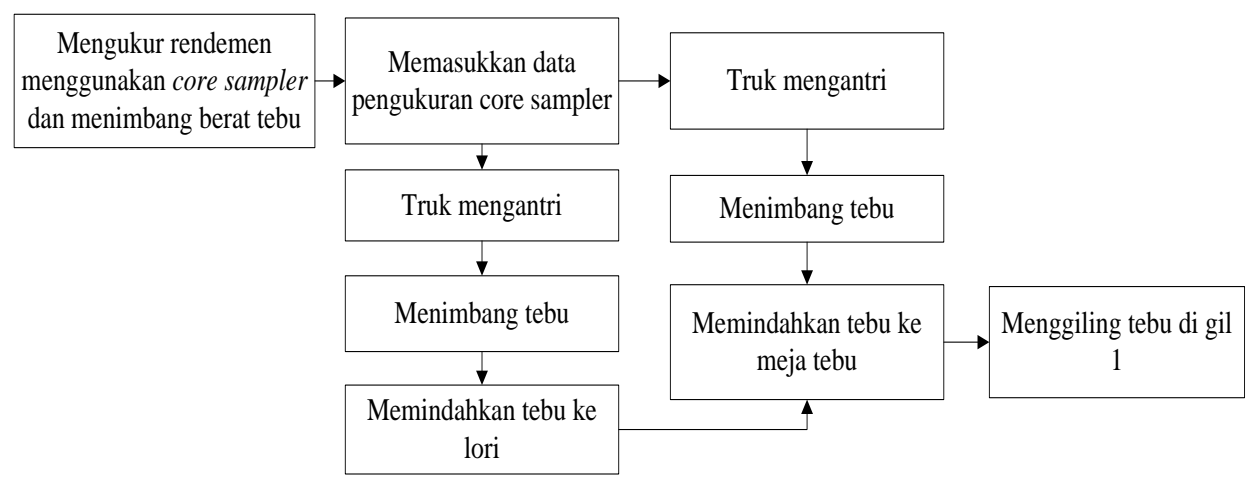

Gambar 6. Mekanisme usulan alur pengukuran rendemen tebu petani menggunakan core sampler 
Strukturisasi Sistem Kelembagaan Produktivitas Bagi Hasil Agroindustri Gula dalam Kemitraan Antara Petani dan PG

Bentuk mekanisme kelembagaan di PG Kremboong terdiri dari Pabrik Gula, kelompok tani, APTR (Asosiasi petani tebu rakyat), KPTR (Koperasi petani tebu rakyat), Dinas Perkebunan, dan Lembaga Penelitian. Ilustrasi dan hubungan kelembagaan yang terjalin antar pelaku di PG Kremboong saat ini (Gambar 7).

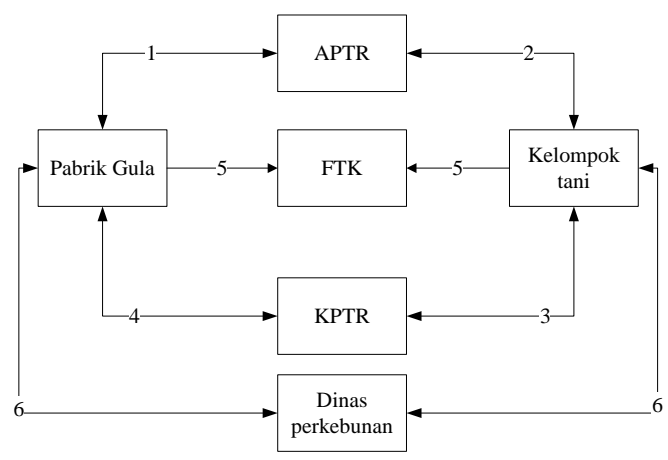

Gambar 7. Ilustrasi kelembagaan saat ini

Ilustrasi hubungan kelembagaan pada Gambar 7 menimbulkan beberapa permasalahan yaitu ketidakpercayaan dalam hal pengukuran rendemen antara petani dan perusahaan. Oleh karena itu diperlukan model kelembagaan produktivitas bagi hasil dengan tujuan untuk meningkatkan kepercayaan antar pelaku. Penyusunan model kelembagaan produktivitas bagi hasil dengan menganalisis elemen tujuan, elemen kebutuhan, elemen kendala, dan elemen pelaku. Elemen-elemen dan sub elemen meliputi: 1) elemen tujuan yang terdiri dari keadilan antara petani dan PG, mendapatkan jaminan pendapatan tebu, meningkatkan kepercayaan antara petani dan PG, dan peningkatan motivasi petani untuk menanam tebu; 2) elemen kendala terdiri dari ketidakpercayaan petani terhadap pengukuran rendemen, budaya tebu yang berorientasi pada bobot, belum tersedianya pengukuran rendemen secara individu yang lebih akurat dan terpercaya, moral hazard, dan ketidaktersediaan lembaga pendukung; 3) elemen kebutuhan terdiri dari ketersediaan dan kelancaran akses modal dan fasilitas kredit petani, ketersediaan alat untuk mengukur rendemen tebu secara individu (core sampler), tersedianya perjanjian kontrak kerjasama, tim pengawas dan pengamat rendemen, dan undangundang tentang bagi hasil; dan 4) elemen pelaku yang terdiri dari Pabrik Gula Kremboong, Kelompok tani, Koperasi Petani Tebu Rakyat (KPTR), Asosiasi Petani Tebu Rakyat (APTR), Dinas perkebunan, dan Lembaga peneliti (Universitas dan pusat penelitian gula).
Masing-masing elemen dan sub elemen dianalisis menggunakan ISM dan berdasarkan informasi dari pendapat pakar. Pertama, hasil analisis ISM untuk elemen tujuan menunjukkan bahwa kepercayaan antara petani dan perusahaan akan terbentuk apabila adanya keadilan, adanya jaminan pendapatan untuk petani tebu yang akan mempengaruhi terhadap kepercayaan dan motivasi petani untuk menanam tebu dan berkerjasama dengan pihak perusahaan. Hasil elemen kunci tujuan berupa keadilan ini menjadi titik perhatian untuk pelaku-pelaku dimulai dari petani, KPTR, APTR, Dinas Perkebunan, dan Pabrik Gula yang akan menjadi tolak ukur kelancaran dalam pasokan bahan baku dan kerjasama. Artinya, dengan mengetahui elemen kunci ini akan meningkatkan kelancaran dan kemudahan untuk memantau serta mengevaluasi jalannya suatu lembaga. Strukturisasi elemen tujuan dapat dilihat pada Gambar 8.

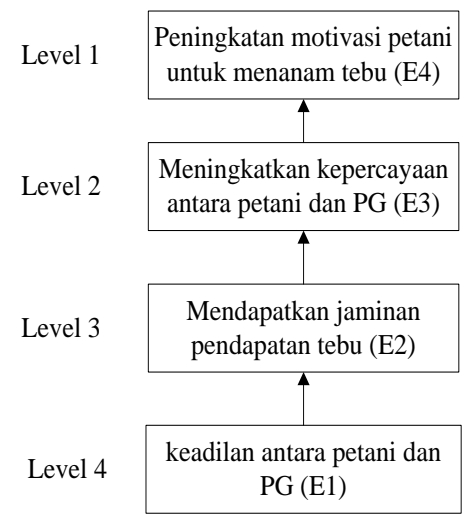

Gambar 8. Struktur hirarki antar sub elemen tujuan

Kedua, hasil analisis elemen kunci kendala dijadikan sebagai informasi untuk sebuah kelembagaan yang terdiri dari beberapa pelaku agar supaya mudah untuk pemantauan, penanganan dari munculnya kendala yang terjadi terkait dengan penyusunan model kelembagaan produktivitas bagi hasil. Elemen kunci kendala menunjukkan bahwa kendala belum tersedianya pengukuran rendemen secara individu yang lebih akurat dan terpercaya serta ketidaktersediaan lembaga pendukung akan mempengaruhi produktivitas bagihasil. Elemen kunci tersebut yang mempengaruhi terhadap tujuan yaitu kepercayaan antara petani dan perusahaan. Strukturisasi elemen kendala (Gambar 9).

Ketiga, pengetahuan akan elemen kunci kendala akan mempermudah untuk menyusun elemen kebutuhan untuk penyusunan model kelembagaan produktivitas bagi hasil. Ketiadaan pengukuran rendemen secara individu dan lembaga pendukung membutuhkan solusi untuk mengatasi kendala dalam kelembagaan yang berjalan. 


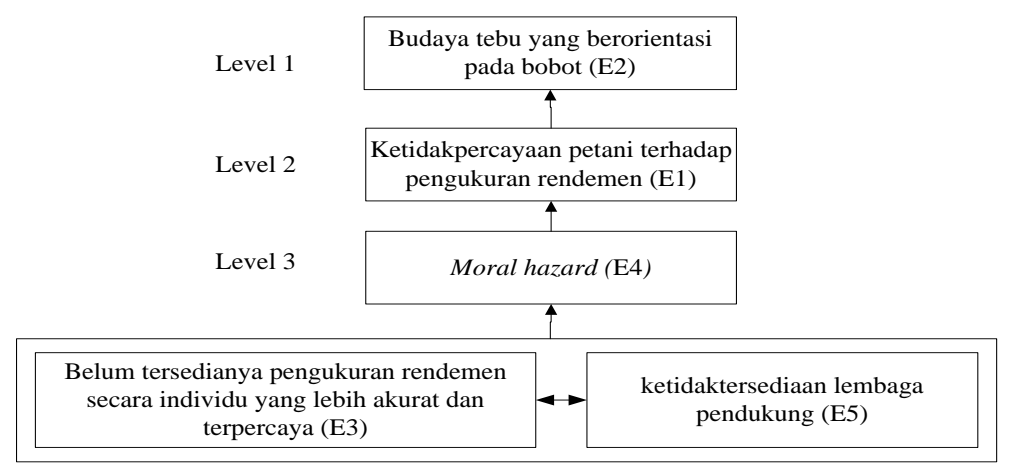

Gambar 9. Struktur hirarki antar sub elemen kendala

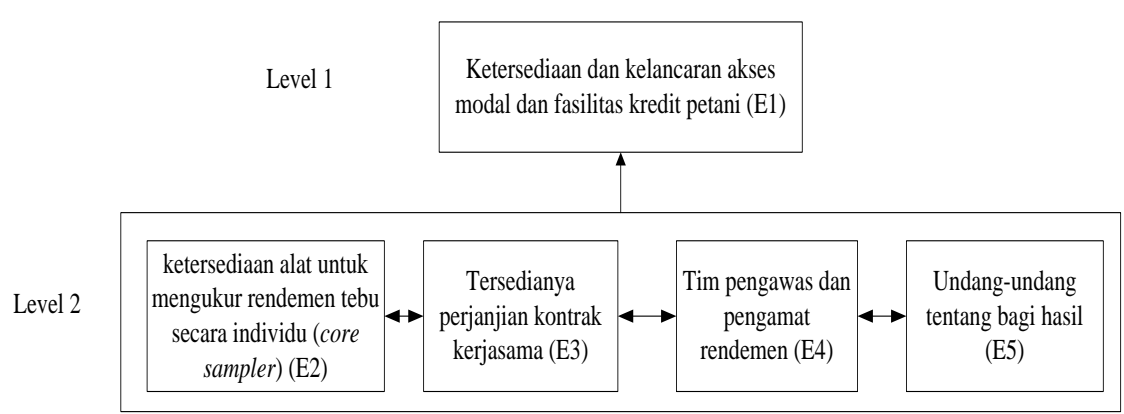

Gambar 10. Struktur hirarki antar sub elemen kebutuhan

Solusi yang dapat mengatasi yaitu adanya pengukuran core sampler untuk mengukur rendemen secara individu yang dilengkapi dengan adanya tim pengawas dan pengamat rendemen serta adanya kontrak kerjasama yang diiringi oleh undang-undang bagi hasil akan memberikan kelancaran dari penyusunan model kelembagaan produktivitas bagi hasil. Solusi tersebut dapat disusun pada elemen kebutuhan. Strukturisasi elemen kebutuhan (Gambar 10).

Keempat, hasil elemen kunci pelaku dapat digunakan untuk menganalisis keterlibatan pelaku dalam kelembagaan dengan mengetahui elemen kunci tujuan, elemen kunci kendala, dan elemen kunci kebutuhan. Nantinya terpilih elemen kunci pelaku yang tepat dengan permasalahan yang ada untuk menyusun model kelembagaan produktivitas bagi hasil. Elemen kunci pelaku terpilih yaitu lembaga peneliti yang terdiri dari tim peneliti, pihak perusahaan, dan perwakilan petani. Justifikasi dari terpilihnnya lembaga peneliti karena kemampuan berdasar pengetahuan tentangpengukuran,akurasi dantransparansi rendemen.

Tim peneliti yaitu tim pelaksana yang mengetahui formula sertameneliti pengukuran rendemen dan permasalahan rendemen.Dengan demikian, tim peneliti telah mengetahui tentang pengukuran dan transaparansi rendemen. Pihak perwakilan petani yaitu ketua dari APTR serta pihak PG yang dianggap mewakili petani dan perusahaan yang merupakan pelaku yang terlibat langsung dilapang dan dipercaya dalam pengukuran rendemen. Kepercayaan dan kemampuan dalam pengukuran transparansi rendemen menjadi dasar untuk justifikasi elemen kunci pelaku. Akhirnya, penyusunan model kelembagaan yang dihasilkan (Gambar 11).

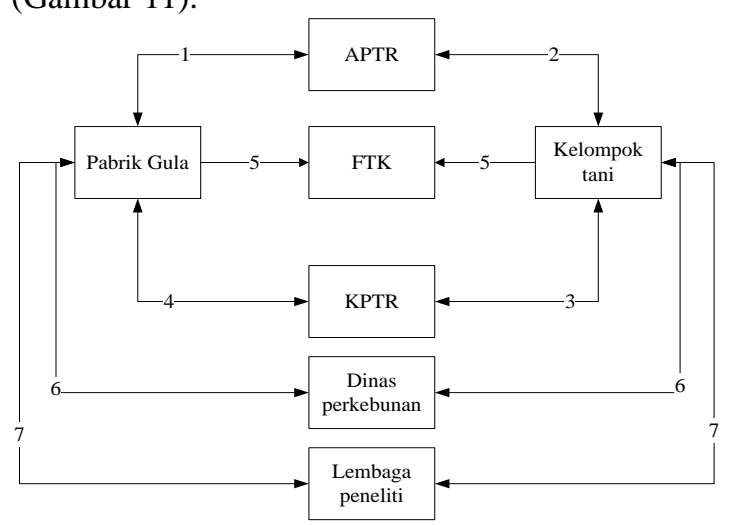

Gambar 11. Ilustrasi rekomendasi model kelembagaan

Gambar 7 dan 11 menunjukkan kelembagaan saat ini dan rekomendasi kelembagaan agroindustri gula tebu yang berlokasi di Sidoarjo. Peran dan fungsi masing-masing lembaga sebagai berikut :

1. Nomor 1 menununjukkan bahwa PG dan APTR bertindak sebagai avalis dan penyusunan kebijakan dan negosiasi,

2. Nomor 2 menunjukkan bahwa berperan untuk memperjuangkan aspirasi dan kepentingan dari kelompok tani yang berkaitan dengan keberlangsungan dan kelancaran tebu,

3. Nomor 3 menunjukkan bahwa KPTR sebagai penyedia untuk pembiayaan kebutuhan usaha tani tebu, penyaluran obat, dan pupuk serta 
peminjaman alat tebang angkut dan tenaga kerja yang dibutuhkan oleh petani. Sumber pembiayaan berasal dari pihak Bank yang bekerjasama dengan PG, APTR, dan KPTR,

4. Nomor 4 menunjukkan bahwa PG menyusun dan mengontrol berjalannya perjanjian akan kredit pembiayaan yang terjalin antara petani dengan KPTR,

5. Nomor 5 adanya Forum temu kemitraan berfungsi sebagai wadah penyelesaian masalah yang terjadi antara petani dengan PG dan monitoring $\mathrm{PG}$ untuk petani tebu

6. Nomor 6 Dinas perkebunan melakukan monitoring dan dukungan kebijakan akan kelancaran PG dan juga memberikan penyuluhan serta dukungan kebijakan kepada pihak kelompok tani

7. Nomor 7 Lembaga peneliti memiliki peranan sebagai tim independen yang terdiri dari peneliti universitas, peneliti dari pusat penelitian gula Indonesia, pihak perusahaan, dan perwakilan petani. Tim independen ini berfungsi untuk mengontrol dan mengawasi jalannya pengukuran rendemen tebu oleh perusahaan.

\section{Penyusunan Rekomendasi Strategi}

Penentuan Posisi Menggunakan SWOT

Hasil perhitungan strategi internal dan eksternal, diperoleh skor internal 2,789 dan eksternal 3,142 yang artinya faktor internal dan eksternal mempengaruhi produktivitas bagi hasil antara petani dan perusahaan. Hasil ini menentukan posisi PG Kremboong yaitu pada kuadran IV yang didasarkan pada sumbu $(\mathrm{x}, \mathrm{y})$ sama-sama negatif yaitu $(-0,207$; 0,768 ) yangmenunjukkan bahwa PG berada pada posisi lemah dan menghadapi tantangan besar. Oleh karena itu, strategi yang diberikan adalah strategi bertahan, dengan mengendalikan kinerja internal agar tidak semakin memburuk dengan tujuan untuk perbaikan perusahaan.

\section{Pemilihan Strategi Terbaik untuk Meningkatkan Produktivitas Bagi Hasil}

Identifikasi SWOT berdasarkan faktor internal dan faktor eksternal menghasilkan 11 faktor kekuatan, 10 faktor kelemahan, 5 faktor peluang, dan 6 faktor berupa ancaman. Hasil identifikasi eksternal dan internal faktor kemudian digunakan untuk menyusun alternatif strategi dengan mengagregasikan SWOT dan AHP. Hasil analisis SWOT-AHP memperoleh 21 strategi rekomendasi yang dapat mewujudkan tercapainya produktivitas bagi hasil dalam agroindustri gula antara petani dan PG antara lain. Tiga nilai bobot tertinggi pada strategi rekomendasi meliputi: 1) pengelolaan lahan tebu yang dapat terintegrasi dalam pengelolaan pabrik gula dengan nilai bobot 0,170 . Hal ini akan meningkatkan nilai rendemen karena pemantauan dan pengawasan langsung dibawah PG (Purwono, 2002); 2) Penerapan sistem beli putus akan menguntungkan petani karena petani tidak menanggung risiko tingkat efisiensi pabrik dan ketidaklancaran proses pengolahan dengan nilai bobot 0,116; dan 3) Peningkatan jalinan kerjasama dan koordinasi yang baik dengan petani dengan nilai bobot 0,115 .

\section{KESIMPULAN DAN SARAN}

\section{Keimpulan}

Faktor-faktor yang nyata mempengaruhi rendemen dalam produktivitas bagi hasil adalah kualitas tebu, nilai brix, dan nilai pol. Hasil model prediksi nilai rendemen menggunakan regresi linier berganda adalah $7,17 \%$ dengan nilai $r^{2} 100 \%$. Nilai rendemen menjadi dasar untuk mengetahui perolehan bagi hasil antara petani dan perusahaan. Berdasarkan hasil penelitian, model produktivitas bagi hasil menghasilkan 3 skenario yaitu sistem bagi hasil untuk skenario ke-1 dan sistem beli putus untuk skenario ke-2 dan ke-3. Keuntungan petani pada saat rendemen $7.17 \%$ untuk skenario ke-1 Rp 15.187.702/ha, skenario ke-2 Rp15.187.702/ha, dan skenario ke-3 mencapai Rp11.631.884/ha. Skenario yang terpilih adalah skenario ke-3.

Model kelembagaan menghasilkan satu sub elemen kunci tujuan yaitu keadilan antara petani dan PG; dua sub elemen kunci kendala yaitu belum tersedianya pengukuran rendemen secara individu yang lebih akurat dan terpercaya, ketersediaan lembaga pendukung; tiga sub elemen kunci kebutuhan yaitu ketersediaan alat untuk mengukur rendemen tebu secara individu, tersedianya perjanjian kontrak kerjasama, tim pengawas dan pengamat rendemen, undang-undang tentang bagi hasil; dan satu sub elemen kunci pelaku yaitu lembaga peneliti. Penyusunan strategi untuk rekomendasi yang terpilih adalah pengelolaan lahan tebu yang terintegrasi dengan pengelolaan pabrik gula dengan nilai bobot 0,170 dan sistem beli putus 0,116 .

\section{Saran}

Perumusan model produktivitas bagi hasil sebaiknya dikelompokkan dengan frame work rule base model dan mempertimbangkan persentase risiko antara petani dan perusahaan. Selain itu, Penyusunan model produktivitas bagi hasil sebaiknya dilakukan dan dibandingkan dengan PG yang lainnya.

\section{DAFTAR PUSTAKA}

Debertin DL. 1986. Agrucultural Production Economics. New York (USA) : Macmillan Publishing.

Eriyatno.1999. Ilmu Sistem: Meningkatkan Mutu dan Efektifitas Manajemen. Bogor (ID): IPB Press. 
Fahrizal, Marimin, Yani M, Purwanto M, Sumaryanto. 2014. Model penunjang keputusan pengembangan agroindustri gula tebu (studi kasus dinusa tenggara timur). Jurnal Teknologi Industri Pertanian. 24(3):189-200.

Gorener A, Toker K, dan Ulucay K. 2012. Application of combined SWOT and AHP: a case study for a manufacturing firm. $8^{\text {th }}$ International Strategic Management Conference. Procedia Social and Behavioral Science. 58: 1525-1534.doi.org/10.1016/ j.sbspro.2012.09.1139.

Indrawanto C, Purwono, Siswanto, Syakir M, Rumini W. 2010. Budidaya dan Pasca Panen Tebu. Jakarta (ID): ESKA Media.

Kim DO. 2005. The benefit and costs of employee suggestion under gainsharing.Industrial and Labor Relations Review. 58(4): 631-652.

[LRPI] Lembaga Riset Perkebunan Indonesia. 2005. Menuju Penentuan Rendemen Tebu yang Lebih Individual. Bogor (ID): LRPI.

Marimin. 2008. Teknik dan Aplikasi Pengambilan Keputusan Kriteria Majemuk. Jakarta (ID): Grasindo Gramedia Widiasarana Indonesia.

Mardianto S. 2005. Peta jalan (road map) dan kebijakan pengembangan industri nasional. Forum Penelitian Agro Ekonomi. 23(1): 1937.

Mulyadi. 2006. Kajian teknik penetapan rendemen tebu individual petani di pabrik gula Mojopanggung Tulung Agung, Jawa Timur. [tesis]. Bogor: Sekolah Pascasarjana, Institut Pertanian Bogor.

Nahdodin. 2012. Sistem bagi hasil yang dapat meningkatkan rendemen. Majalah Penelitian Gula. 48(2):106-112.

Osuna EE dan Aranda A. 2007. Combining SWOT and AHP techniques fos strategic planning. Proceeding of the $9^{\text {th }}$ International Symposium on the Analytical Hierarchy Process; 2007 Agustus 2-6; Vina del Mar.
PeykaniGR, Kelashemi MK, Shahbazi H, Akrami AH. 2010. A determination of suitable sugar cane utilization system using total factor productivity (TFP) (case study: imam khomeini cultivitation and processing center in khuzestan province). Journal of Agricultural Science and Technology. 12: 511-521.

Purwono. 2002. Penggunaan pengukuran brix untuk menduga rendemen nyata di pabrik gula gula putih Mataram, Lampung. Divisi R\&D, Pabrik Gula Putih di Mataram, Lampung.

Rahmatulloh, Marimin, Machfud, Nasution MZ. 2009. Kajian sistem pengukuran kinerja pabrik gula (studi kasus: pg subang jawa barat). Jurnal Manajemen dan Agribisnis. 6(1):14-23.

Ross TL dan Ross RA. 1984. Productivity gainsharing: resolving some of the measurement issues. National Productivity Review: 382-394.

SamosirN, Siagian P, dan Bangun P. 2014. Analisa metode backward dan metode forward untuk menentukan persaman regresi linier berganda. Saintia Matematika. 2(4):345-360.

Saputro R. 2013. Penerapan sistem core sampling di pabrik gula [internet]. [diacu 24 januari 2016]. Tersedia dari: http://sugar.lpp.ac.id/ penerapan-sistem-core-sampling-di-pabrikgula/. tanggal 24 Januari 2016; 17:28 pm.

Sargent RG. 2011. Verification and validation of simulation models. Proceedings of the 20011 Winter Simulation Conference: 183-198.

Suhada B, Sa'id EG, Rusastra IW, Sukardi. 1012. Rekayasa kelembagaan kemitraan pabrik gula dengan petani tebu dalam mendukung peningkatan kinerja industri gula tebu nasional. Jurnal Manajemen dan Kewirausahaan. 4(1):60-74.

Susila WR dan Sinaga BM. 2005. Pengembangan industri gula Indonesia yang kompetitif pada situasi persaingan yang adil. Jurnal Libang Pertanian. 24(1):1-9. 